\title{
AN EVALUATION OF THE EFFECTIVENESS OF NONCONVENTIONAL P FERTILIZERS DERIVED FROM ZIMBABWE PHOSPHATE ROCK USING RYEGRASS AS A TEST CROP
}

\author{
Govere, E.M. ${ }^{1}$, Chien, S.H. ${ }^{2}$ and Fox, R.H. ${ }^{1}$ \\ ${ }^{11}$ Department of Crop and Soil Sciences, Pennsylvania State University, \\ University Park, PA 16802 \\ ${ }^{2}$ International Fertilizer Development Center (IFDC), Muscle Shoals, AL 35662
}

\begin{abstract}
Zimbabwe and many other African countries lack high-quality phosphate ores for the production of conventional phosphate fertilizers. The objective of this study was to investigate the agronomic potential of an igneous phosphate rock derived from Dorowa (Zimbabwe) in a greenhouse experiment using rye grass (Lolium perenne) as test crop on a Hartsells silt loam. Three phosphate fertilizer materials: finely ground (0.150-mm screen) Dorowa phosphate rock (DPR); $D P R$ partially acidulated with $50 \%$ of the sulfuric acid required for complete acidulation (PADPR); and a compacted mixture of DPR + triple superphosphate + urea + potassium chloride (DTUK) with half of phosphorus from DPR and half from TSP were made from Dorowa rock and their agronomic effectiveness compared with that of single superphosphate. The relative agronomic effectiveness of the fertilizers based on dry matter yield of ryegrass followed the orders: $D T U K=S S P>P A D P R>D P R=$ Check and $S S P>D T U K=P A D P R>D P R=$ Check during the first 12 weeks and the second 12 weeks, respectively. For phosphorus uptake by ryegrass, the orders were: $D T U K>S S P>P A D P R>D P R=$ Check, $D T U K=S S P>P A D P R>D P R=$ Check, and $S S P>D T U K>P A D P R>D P R=$ Check during the first six, second six, and last 12 weeks, respectively. The results confirmed that the effectiveness of DPR could be greatly enhanced by partially acidulating DPR or compacting DPR with TSP, urea, and $\mathrm{KCl}$.
\end{abstract}

\section{INTRODUCTION}

The main phosphate deposits in Zimbabwe are the 37 million metric tons of the Dorowa deposit (McClellan and Notholt, 1986). Dorowa phosphate rock (DPR) has an approximate composition of $\mathrm{Ca}_{10}\left(\mathrm{PO}_{4}\right)_{6}\left(\mathrm{~F}_{1.08}, \mathrm{OH}_{0.92}\right)(\mathrm{Van}$ Kanwenbergh, 1989). It is an igneous hydroxyfluorapatite with $\mathrm{MgO} / \mathrm{P}_{2} \mathrm{O}_{5}, \mathrm{CaO} / \mathrm{P}_{2} \mathrm{O}_{5},\left(\mathrm{Fe}_{2} \mathrm{O}_{3}+\mathrm{Al}_{2} \mathrm{O}_{3}\right) /$ $\mathrm{P}_{2} \mathrm{O}_{5}$, and $\left(\mathrm{Fe}_{2} \mathrm{O}_{3}+\mathrm{Al}_{2} \mathrm{O}_{3}+\mathrm{MgO}\right) / \mathrm{P}_{2} \mathrm{O}_{5}$ weight ratios that are higher than the levels considered desirable for the production of conventional phosphorus $(\mathrm{P})$ fertilizers such as single superphosphate (SSP) and triple superphosphate (TSP). The higher these ratios the greater the sulfuric acid $\left(\mathrm{H}_{2} \mathrm{SO}_{4}\right)$ consumption for wet-process phosphoric acid production (Roy and McClellan, 1985); and the greater the post precipitation of sludge in phosphoric acid, scale formation on equipment during phosphoric acid concentration, insoluble phosphoric compounds in liquid or solid ammonium phosphate products, and unwanted agglomeration in non solid ammonium polyphosphate (Becker, 1989). Abundant iron and aluminum can also cause reversion of available $\mathrm{P}$ to an unavailable form in superphosphate-type products (Roy and McClellan, 1985). In addition to the problem of undesirable metal oxides to $\mathrm{P}_{2} \mathrm{O}_{5}$ ratios, DPR is unreactive because as an apatite from igneous sources, it is coarsely crystalline and does not possess internal surfaces (Khasawneh and Doll, 1978; Leon et al., 1986).

The dissolution of, and $\mathrm{P}$ availability from, noconventional fertilizer materials depend on many factors. These factors include the fertilizer characteristics (Hammond et al., 1986), soil chemical characteristics (Govere et al., 2004) and in some cases, the plant that is grown in the fertilized soil (Khasawneh and Copeland, 1973). Govere et al. (1995, 2003) tested the initial and residual effectiveness of finely ground $(0.150-\mathrm{mm}$ 
screen) Dorowa phosphate rock (DPR); DPR partially acidulated with $50 \%$ of the sulfuric acid required for complete acidulation (PADPR); and a compacted mixture of DPR + triple superphosphate + urea + potassium chloride (DTUK) on a short-term basis (six weeks each duration) using maize (Zea mays $L$ ) in a greenhouse experiment. The results from the initial six-week maize showed that DTUK, PADPR, and DPR were $108 \%, 75 \%$ and $0 \%$ as effective as SSP (100 $\%)$ in increasing dry matter yield. However, the residual effectiveness assessed by planting a second maize crop for six weeks in the same pots immediately after harvesting the first maize crop without additional P dropped to $74 \%$ and 56 $\%$ for DTUK and PADPR, respectively. There was need to assess the effectiveness of these fertilizer materials using a different plant to further evaluate their agronomic effectiveness.

The objective of this study was to evaluate the agronomic effectiveness of the nonconventional PR fertilizer materials derived from Dorowa phosphate rock in increasing dry matter yield of, and $\mathrm{P}$ uptake by ryegrass. Ryegrass has high root surface area (well-developed fibrous roots) and can grow for a relatively long period. The advantage of using a perennial species like ryegrass is that successive and cumulative cuttings can be made upon which $\mathrm{P}$ availability from PR based fertilizers would be evaluated by comparing relative agronomic effectiveness of the $\mathrm{P}$ sources against a standard P fertilizer (Xiong et al., 1994). Such a study reveals the initial, intermediate, and longterm effects of $\mathrm{P}$ sources and is relevant in screening $\mathrm{P}$ fertilizer sources for agronomic use.

\section{MATERIALSAND METHODS}

\section{Phosphate Fertilizer Materials}

Three phosphate fertilizer materials were made from Dorowa (Zimbabwe) phosphate rock: (1) finely ground Dorowa phosphate rock (DPR); (2) 50\% acidulated DPR (PADPR); and (3) compacted product of DPR + triple superphosphate + urea + potassium chloride (DTUK). The DPR fertilizer material was made by grinding the phosphate rock to pass a 0.150 -mm screen (100-mesh). The PADPR fertilizer material was prepared by acidulating Dorowa rock with $50 \%$ of sulfuric acid required to produce a commercial grade single superphosphate (Schultz, 1986). The DTUK fertilizer material was made by first grinding separately Dorowa rock, triple superphosphate (TSP), urea, and $\mathrm{KCl}$ into powder, and then mixing appropriate amounts to produce $\mathrm{N}: \mathrm{P}_{2} \mathrm{O}_{5}: \mathrm{K}_{2} \mathrm{O}$ ratio of $1: 1: 1$. The ratio of total $\mathrm{P}$ from DPR and TSP was 50:50. After mixing, the product was physically compacted by applying pressure equal to $9 \mathrm{Mg} \mathrm{cm}^{-1}$ using a laboratory hydraulic compactor (Lupin and Le, 1983). Both the 50\% acidulated and the compacted products were crushed and screened to particle sizes smaller than $3.36 \mathrm{~mm}$ but larger than 1.19 $\mathrm{mm}$. A commercial grade SSP was used as a standard to compare the agronomic effectiveness of the Dorowa based fertilizers. The total $\mathrm{P}_{2} \mathrm{O}_{5}$, water-soluble and neutral ammonium citrate soluble $\mathrm{P}_{2} \mathrm{O}_{5}$ of the fertilizers used in the study are shown in Table 1 .

Table 1 Selected characteristics of $P$ fertilizer sources used in the experiment

\begin{tabular}{lccccc}
\hline & & \multicolumn{3}{c}{$\% \mathrm{P}_{2} \mathrm{O}_{5}$ of P Source Soluble in } & \\
\cline { 3 - 5 } P Source $\dagger$ & Total $\mathrm{P}_{2} \mathrm{O}_{5}, \%$ & Water & Citrate $\neq$ & Water + Citrate & As \% of Soluble SSP \\
\cline { 3 - 5 } & & & & & \\
\hline DPR & 33.3 & 0 & 0.8 & 0.8 & 4 \\
PADPR & 25.2 & 8.7 & 1.1 & 9.8 & 53 \\
DTUK & 16.6 & 6.6 & 2.7 & 9.3 & 50 \\
SSP & 19.4 & 15 & 3.6 & 18.6 & 100 \\
\hline
\end{tabular}

$\dagger \mathrm{DPR}=$ Finely ground Dorowa phosphate rock (to pass 0.150 -mm screen).

PADPR $=$ Partially acidulated Dorowa phosphate rock $\left(50 \% \mathrm{H}_{2} \mathrm{SO}_{4}\right)$.

DTUK = Compacted DPR + TSP + urea $+\mathrm{KCl}\left(\mathrm{N}_{2} \mathrm{P}_{2} \mathrm{O}_{5}: \mathrm{K}_{2} \mathrm{O}=1: 1: 1\right)$.

SSP $=$ Single superphosphate (commercial grade).

PADPR and DTUK were in granular form $(<3.36\rangle ,1.19 \mathrm{~mm})$ and the P ratio of DPR:TSP was 50:50 for the compacted material (DTUK).

¥Does not include water-soluble P. 


\section{Greenhouse Study}

A bulk soil sample from an Ap horizon of a Hartsells silt loam (Typic Hapludult; fine loamy, silicious, thermic; $\mathrm{pH} 4.8$ [1:1 soil: water], organic matter $48 \mathrm{~g} \mathrm{~kg}^{-1}$, Bray 1-P $8 \mathrm{mg} \mathrm{P} \mathrm{kg}^{-1}$, and CEC $9.5 \mathrm{cmol} \mathrm{kg}^{-1}$ ) from Tennessee was air dried, and screened to less than $2 \mathrm{~mm}$. Four-kilogram soil samples were placed in pots. Potassium chloride and urea were added to each pot and thoroughly mixed to give a constant total content of $300 \mathrm{mg} \mathrm{K} \mathrm{kg}^{-1}$ and $300 \mathrm{mg} \mathrm{N} \mathrm{kg}^{-1}$ of soil. Onekilogram soil samples were removed from the top of pots and mixed with phosphorus fertilizer materials at 25, 50, 75,100 and $150 \mathrm{mg} \mathrm{P} \mathrm{kg}^{-1}$. A nutrient solution containing 31 $\mathrm{mg} \mathrm{Mg}, 6 \mathrm{mg} \mathrm{Zn,} 2 \mathrm{mg} \mathrm{Cu}, 1.5 \mathrm{mg} \mathrm{B}$, and $14 \mathrm{mg} \mathrm{S}$ was added to each $1-\mathrm{kg}$ soil sample. Each $1-\mathrm{kg}$ soil sample was thoroughly mixed in a container, and then returned on top of the $3-\mathrm{kg}$ soil sample in the pots without mixing the soil.

Fifty grams (of dry soil) were removed from each pot and the remaining soil was leveled. Adequate water was added to the pots to ensure good seed emergence. About $0.6 \mathrm{~g}$ (about 300 seeds) of ryegrass seeds was uniformly sprinkled onto the surface of each pot. The seeds were covered very lightly with $50 \mathrm{~g}$ of dry soil to ensure proper germination. The pots were placed in a greenhouse in a randomized block design with three replicates. The pots were watered daily with de-ionized water to maintain soil moisture at approximately $80 \%$ of container capacity. As a precaution, saucers were placed at the bottom of the pots to collect any leachate, which would then be returned to the respective pot. The air temperature in the greenhouse ranged from 16 to $26^{\circ} \mathrm{C}$. To minimize the effect of the pot location on ryegrass growth, the pot position within each block was randomly rearranged on a weekly basis. At about 6-week intervals, the ryegrass was cut to $3 \mathrm{~cm}$ from the pot soil surface. In total, 4 cuttings were made. The harvested ryegrass was dried at $65^{\circ} \mathrm{C}$ and dry matter yield was determined.

After dry-matter yield was determined, ryegrass plant tissue was ground to less than $3 \mathrm{~mm}$. The ground plant samples were digested in 2:1 $\mathrm{HNO} 3: \mathrm{HClO} 4$ mixture. To test for soil P, the soil in the pots was mixed and 100-g (dry weight) soil samples were taken from each pot. The soil samples were ground to pass a $2 \mathrm{~mm}$ screen. Available soil P was extracted by the Bray P-1 soil test (Bray and Kurtz, 1945). The $P$ in both soil extracts and ryegrass plant tissue digests was measured by the ammonium molybdate ascorbic acid method (Watanabe and Olsen, 1965).

\section{Data Analysis}

Analysis of variance to determine the significance of treatment effects was performed using the Statistical Analysis System (SAS, 1990). The analysis for dry matter yield of, and $\mathrm{P}$ uptake by ryegrass was based on factorial treatment combinations in a randomized complete block design. Analyses of variance were done on both the successive and cumulative dry matter yield and P uptake, and were expressed as percentage of total sum of square (SS) to show the extent of each source of variation (Hellums et al., 1989). Analyses of variance were also made at 25,50 , and $75 \mathrm{mg} \mathrm{P} \mathrm{kg}^{-1}$ soil in order to compare the effectiveness of the $\mathrm{P}$ sources in increasing dry matter yield and $\mathrm{P}$ uptake per unit of water and citrate soluble P applied. Fisher's protected least significant difference (lsd) was used to make pairwise comparisons of treatment means (Steel and Torrie, 1980).

The relationships between dry matter yield or P uptake and fertilizer P rate applied were expressed as

$$
Y_{i}=\beta_{o}+\beta_{i} X+\sum_{i}
$$

or

$$
Y_{i}=\beta_{o}+\beta_{i} \log (X)+\sum_{i}
$$

where $\mathrm{Y}_{\mathrm{i}}$ is the dry matter yield or $\mathrm{P}$ uptake obtained with source $\mathrm{i}, \mathrm{X}$ is the rate of $\mathrm{P}$ applied, $\beta_{i}$ is the regression coefficient of the response function, $\beta_{o}$ is the intercept, and $\sum_{i}$ is the error term of the fitted model. A t-statistic was used to test the null hypothesis $H_{a}: \beta_{1}=0$, against an alternative $H_{a}: \beta_{1} \neq 0$ for individual regression coefficients for the different $\mathrm{P}$ sources. The standard errors $\left(S E_{\beta}\right)$ of estimate for regression coefficients $\left(\beta_{i}\right)$ were used to test whether the regression coefficient of a $\mathrm{P}$ source was statistically different from that of the other sources (Chien et al., 1986).

To evaluate the efficiency of response to fertilizer over the range of P rates used, a Relative Crop Response index (RCRi), defined as the ratio of two regression coefficients was used (Chien et al., 1990). The ratio represents the increase of yield or P uptake compared to that of a standard source per unit of 
P fertilizer applied (Menon and Chien, 1990). It is mathematically expressed as:

$$
R C R_{i}=\left(\beta_{i} / \beta_{S S P}\right) X 100
$$

where $\left(\beta_{i}\right)$ is the regression coefficient of a $\mathrm{P}$ source and $\hat{\mathrm{a}}_{\mathrm{SSP}}$ the regression coefficient of the standard (SSP) used. The $\mathrm{RCR}_{\mathrm{i}}$ for dry matter yield or P uptake for a given source of P was then calculated against SSP as $100 \%$. Statistical differences between regression coefficient values also meant significant differences between $\mathrm{RCR}_{\mathrm{i}}$ values.

\section{RESULTS}

\section{First Cut Ryegrass Dry Matter Yield and P Uptake}

The results of analysis of variance for the dry matter yield of, and $\mathrm{P}$ uptake by ryegrass for the combined four cuttings are given in Table 2. Variations in dry matter yield and $\mathrm{P}$ uptake due to effects of $\mathrm{P}$ sources, $\mathrm{P}$ rates, cuttings, and interactions between the $\mathrm{P}$ source, rates, and cuttings were highly significant $(\mathrm{P}<0.01)$. About 70 $\%$ of the variations in dry matter yield and $\mathrm{P}$ uptake were due to $\mathrm{P}$ sources and $\mathrm{P}$ rates. The $\mathrm{P}$ sources, $\mathrm{P}$ rates, cuttings, and the interactions between them accounted for $97 \%$ of the variations in dry matter yield and $98 \%$ of the variations in $\mathrm{P}$ uptake (Table 2). The means for all $\mathrm{P}$ rates for dry matter yield and $\mathrm{P}$ uptake obtained with the $\mathrm{P}$ sources for successive and cumulative cuttings are given in Table 3. At first cutting and for combined first and second cuttings, SSP and DTUK were equally effective in increasing dry matter yield of ryegrass. At the third and fourth cuttings, SSP was more effective than DTUK and there was no significant difference between PADPR and DTUK. However, the cumulative data over the four cuttings showed DTUK remained more effective than PADPR. For SSP, DTUK and PADPR, the second and third cuttings accounted for $60 \%$ of the total dry matter yield of the four cuttings. As was expected, the DPR was ineffective in increasing dry matter yield. It yielded the same as the check treatment.

The effectiveness of $\mathrm{P}$ sources can be estimated using $\mathrm{P}$ uptake amounts by a plant. In this study, the effect of $\mathrm{P}$ sources on $\mathrm{P}$ uptake by ryegrass was different from their effect on dry matter yield. The DTUK treatment resulted in more P uptake than SSP for the first cutting. The differences among $\mathrm{P}$ sources were greater with $\mathrm{P}$ uptake than with dry matter yield. At all the four cuttings, $P$ uptake by ryegrass was significantly different among $\mathrm{P}$ sources (Table 3). Initially, DTUK had the highest P uptake but after the first cutting, SSP had the highest $\mathrm{P}$ uptake. When dry matter for the first and second cuttings were combined, SSP and DTUK had same effects on P uptake by ryegrass.

In order to measure the relative agronomic effectiveness of the P sources relative to a standard (SSP) source, several

Table 2. Analysis of variance of cumulative dry matter yield of, and $P$ uptake by ryegrass

\begin{tabular}{|c|c|c|c|}
\hline \multirow[b]{2}{*}{ Source of variation } & \multirow[b]{2}{*}{$\mathrm{df}$} & Dry Matter Yield & P Uptake \\
\hline & & \multicolumn{2}{|c|}{$\%$ of Total Adjusted SS $\dagger$} \\
\hline Block & 2 & 0.6 & 0.4 \\
\hline P source & 4 & $57 * *$ & $51 * *$ \\
\hline$P$ rate & 4 & $11^{* *}$ & $18 * *$ \\
\hline Cuttings & 3 & $10 * *$ & $9 * *$ \\
\hline $\mathrm{P}$ source $\mathrm{x} P$ rate & 12 & $4 * *$ & $7 * *$ \\
\hline P source $x$ Cuttings & 9 & $5 * *$ & $6^{* *}$ \\
\hline$P$ rate $x$ Cuttings & 12 & $5^{* *}$ & $5^{* *}$ \\
\hline P source $\mathrm{x}$ Prate $\mathrm{x}$ Cuttings & 36 & $3 * *$ & $3 * *$ \\
\hline Error & 166 & 3 & 2 \\
\hline $\mathrm{CV} \%$ & & 14 & 15 \\
\hline General Mean & & $1.83 \mathrm{~g} \mathrm{pot}^{-1}$ & $2.35 \mathrm{mg} \mathrm{pot}^{-1}$ \\
\hline SE & & $0.27 \mathrm{~g} \mathrm{pot}^{-1}$ & $0.36 \mathrm{mg} \mathrm{pot}^{-1}$ \\
\hline $\mathrm{R}^{2}$ & & 0.97 & 0.98 \\
\hline
\end{tabular}

$\dagger$ The results are expressed as a percentage of the adjusted total variation by using a Type 1 sum of squares

${ }^{* *}$ Significant at 0.01 probability level. 
An Evaluation of the Effectiveness of Nonconventional P Fertilizers derived from Zimbabwe Phosphate Rock using Ryegrass as a Test Crop

Table 3: Dry matter yield of, and $P$ uptake by ryegrass as affected by different $P$ sources with successive and cumulative cuttings

\begin{tabular}{|c|c|c|c|c|c|c|c|c|}
\hline \multirow[t]{2}{*}{ P Sources } & \multicolumn{4}{|c|}{ Successive Cuttings $\dagger$} & \multicolumn{4}{|c|}{ Cumulative Cuttings } \\
\hline & $1^{\text {st }}$ & $2^{\text {nd }}$ & $3^{\text {rd }}$ & $4^{\text {th }}$ & 1 & 2 & 3 & 4 \\
\hline & \multicolumn{8}{|c|}{ Dry matter yield $\left(\mathrm{g} \mathrm{pot}^{-1}\right)$} \\
\hline Check & $0.36 \mathrm{c}$ & $0.43 \mathrm{~d}$ & $0.62 \mathrm{c}$ & $0.44 \mathrm{c}$ & $0.36 \mathrm{c}$ & $0.80 \mathrm{c}$ & $1.42 \mathrm{~d}$ & $1.85 \mathrm{~d}$ \\
\hline DPR & $0.34 \mathrm{c}$ & $0.37 \mathrm{~d}$ & $0.53 c$ & $0.38 \mathrm{c}$ & $0.34 \mathrm{c}$ & $0.71 \mathrm{c}$ & $1.23 \mathrm{~d}$ & $1.62 \mathrm{~d}$ \\
\hline PADPR & $1.68 \mathrm{~b}$ & $2.34 \mathrm{c}$ & $2.67 \mathrm{~b}$ & $1.80 \mathrm{~b}$ & $1.68 b$ & $4.01 \mathrm{~b}$ & $6.68 \mathrm{c}$ & $8.47 \mathrm{c}$ \\
\hline DTUK & $2.14 \mathrm{a}$ & $2.77 \mathrm{~b}$ & $2.8 \mathrm{ab}$ & $1.75 b$ & $2.14 \mathrm{a}$ & $4.91 \mathrm{a}$ & $7.71 b$ & $9.43 b$ \\
\hline SSP & $2.00 \mathrm{a}$ & $3.07 \mathrm{a}$ & $3.74 a$ & $2.03 \mathrm{a}$ & $2.00 \mathrm{a}$ & $5.07 \mathrm{a}$ & $8.81 \mathrm{a}$ & $10.84 \mathrm{a}$ \\
\hline \multirow[t]{2}{*}{ Lsd 0.05} & 0.23 & 0.19 & 0.19 & 0.15 & 0.23 & 0.33 & 0.34 & 0.35 \\
\hline & \multicolumn{8}{|c|}{ P uptake (mg pot ${ }^{-1}$ ) } \\
\hline Check & $0.29 \mathrm{~d}$ & $0.32 d$ & $0.48 \mathrm{~d}$ & $0.30 \mathrm{~d}$ & $0.29 \mathrm{~d}$ & $0.61 \mathrm{c}$ & $1.10 \mathrm{~d}$ & $1.39 \mathrm{~d}$ \\
\hline DPR & $0.28 \mathrm{~d}$ & $0.29 \mathrm{~d}$ & $0.41 d$ & $0.27 d$ & $0.28 \mathrm{~d}$ & $0.57 \mathrm{c}$ & $0.98 \mathrm{~d}$ & $1.25 \mathrm{~d}$ \\
\hline PADPR & $2.46 \mathrm{c}$ & $2.99 \mathrm{c}$ & $3.11 \mathrm{c}$ & $1.64 \mathrm{c}$ & $2.46 \mathrm{c}$ & $5.45 b$ & $8.55 \mathrm{c}$ & $10.17 \mathrm{c}$ \\
\hline DTUK & $3.63 \mathrm{a}$ & $3.69 \mathrm{~b}$ & $3.41 \mathrm{~b}$ & $1.81 \mathrm{~b}$ & $3.63 \mathrm{a}$ & $7.32 \mathrm{a}$ & $10.74 b$ & $12.54 \mathrm{~b}$ \\
\hline SSP & $3.01 \mathrm{~b}$ & $4.75 \mathrm{a}$ & $5.09 \mathrm{a}$ & $2.40 \mathrm{a}$ & $3.01 \mathrm{~b}$ & $7.76 \mathrm{a}$ & $12.85 \mathrm{a}$ & $15.25 \mathrm{a}$ \\
\hline Lsd 0.05 & 0.35 & 0.29 & 0.21 & 0.12 & 0.35 & 0.52 & 0.62 & 0.58 \\
\hline
\end{tabular}

$\dagger$ Mean values within the same column with same letter are not significantly different at 0.05 probability level

Table 4: Response equations and relative crop response index (RCRi) values for dry matter yield of, and $P$ uptake by ryegrass as affected by different $P$ sources with successive cuttings

\begin{tabular}{|c|c|c|c|c|}
\hline \multirow[t]{3}{*}{ P Source } & \multicolumn{2}{|c|}{ Successive Dry Matter Yield (DMY, g pot $\left.{ }^{-1}\right) \dagger$} & \multicolumn{2}{|c|}{ Successive P Uptake (PUPT, mg pot $^{-1}$ ) } \\
\hline & Response equation $\neq$ & RCRi§ & Response equation & RCRi \\
\hline & \multicolumn{2}{|l|}{$1^{\text {st }}$ cut, linear model, $\mathrm{R}^{2}=0.89 * *$} & \multicolumn{2}{|l|}{$1^{\text {st }}$ cut, linear model, $\mathrm{R}^{2}=0.92 * *$} \\
\hline PADPR & $\mathrm{DMY}=0.404+0.0155 \mathrm{X}(\mathrm{c})$ & $77 \mathrm{~b}$ & PUPT $=0.214+0.0283 \mathrm{X}(\mathrm{c})$ & $80 \mathrm{c}$ \\
\hline DTUK & $\mathrm{DMY}=0.404+0.0210 \mathrm{X}(\mathrm{a})$ & $104 \mathrm{a}$ & PUPT $=0.214+0.0426 \mathrm{X}(\mathrm{a})$ & $120 \mathrm{a}$ \\
\hline \multirow[t]{2}{*}{ SSP } & $\mathrm{DMY}=0.404+0.0202 \mathrm{X}(\mathrm{a})$ & $100 \mathrm{a}$ & PUPT $=0.214+0.0356 \mathrm{X}(\mathrm{b})$ & $100 \mathrm{~b}$ \\
\hline & \multicolumn{2}{|l|}{$2^{\text {nd }}$ cut, linear model, $\mathrm{R}^{2}=0.89 * *$} & \multicolumn{2}{|l|}{$2^{\text {nd }}$ cut, linear model, $\mathrm{R}^{2}=0.92 * *$} \\
\hline PADPR & $\mathrm{DMY}=0.673+0.0208 \mathrm{X}(\mathrm{c})$ & $75 \mathrm{c}$ & PUPT $=0.562+0.0312 \mathrm{X}(\mathrm{c})$ & $62 \mathrm{c}$ \\
\hline DTUK & $\mathrm{DMY}=0.673+0.0245 \mathrm{X}(\mathrm{b})$ & $88 b$ & PUPT $=0.562+0.0372 X(b)$ & $75 b$ \\
\hline \multirow[t]{2}{*}{ SSP } & $\mathrm{DMY}=0.673+0.0278 \mathrm{X}(\mathrm{a})$ & $100 \mathrm{a}$ & PUPT $=0.562+0.0500 X(\mathrm{a})$ & $100 \mathrm{a}$ \\
\hline & \multicolumn{2}{|c|}{$3^{\text {rd }}$ cut, logarithmic model, $\mathrm{R}^{2}=0.87 * *$} & \multicolumn{2}{|c|}{$3^{\text {rd }}$ cut logarithmic model, $\mathrm{R}^{2}=0.91 * *$} \\
\hline PADPR & $\mathrm{DMY}=0.480+0.532 \log (\mathrm{X})(\mathrm{b})$ & $69 \mathrm{~b}$ & PUPT $=0.223+0.707 \log (X)(b)$ & $60 \mathrm{~b}$ \\
\hline DTUK & $\mathrm{DMY}=0.480+0.549 \log (\mathrm{X})(\mathrm{b})$ & $71 b$ & PUPT $=0.223+0.767 \log (X)(b)$ & $66 b$ \\
\hline \multirow[t]{2}{*}{ SSP } & $\mathrm{DMY}=0.480+0.773 \log (\mathrm{X})(\mathrm{a})$ & $100 \mathrm{a}$ & PUPT $=0.223+1.690 \log (X)(a)$ & $100 \mathrm{a}$ \\
\hline & \multicolumn{2}{|l|}{$4^{\text {th }}$ cut logarithmic model, $\mathrm{R}^{2}=0.83^{* *}$} & \multicolumn{2}{|c|}{$4^{\text {th }}$ cut logarithmic model, $\mathrm{R}^{2}=0.93^{* *}$} \\
\hline PADPR & $\mathrm{DMY}=0.421+0.327 \log (\mathrm{X})(\mathrm{b})$ & $87 \mathrm{~b}$ & PUPT $=0.188+0.350 \log (X)(b)$ & $65 b$ \\
\hline DTUK & $\mathrm{DMY}=0.421+0.312 \log (\mathrm{X})(\mathrm{b})$ & $86 b$ & PUPT $=0.188+0.389 \log (X)(b)$ & $73 b$ \\
\hline SSP & $\mathrm{DMY}=0.421+0.375 \log (\mathrm{X})(\mathrm{a})$ & $100 \mathrm{a}$ & PUPT $=0.188+0.535 \log (X)(\mathrm{a})$ & $100 \mathrm{a}$ \\
\hline
\end{tabular}

$\nmid$ DMY and PUPT equations followed by the same letter in brackets within columns are not significantly different from each other $(\mathrm{P}=0.05)$

$¥$ Same lower case letter within columns indicates no significant difference between regression coefficients of the given equations $(\mathrm{P}=0.05)$

§RCRi followed by the same letter in within column per successive or cumulative cuttings are not significantly different from each other $(\mathrm{P}=0.05)$

**Significant at 0.05 probability level 
Table 5: Response equations and relative crop response index (RCRi) values for cumulative dry matter yield of, and $P$ uptake by ryegrass as affected by different $P$ sources

\begin{tabular}{|c|c|c|c|c|}
\hline \multirow[t]{3}{*}{ P Source } & \multicolumn{2}{|c|}{ Cumulative Dry Matter Yield (DMY, g pot $\left.{ }^{-1}\right) \dagger$} & \multicolumn{2}{|c|}{ Cumulative P Uptake (PUPT, mg pot ${ }^{-1}$ ) } \\
\hline & Response equation $\ddagger$ & RCRi§ & Response equation & $\operatorname{RCRi}(\%)$ \\
\hline & \multicolumn{2}{|c|}{1 cutting, linear model, $\mathrm{R}^{2}=0.89 * *$} & \multicolumn{2}{|c|}{1 cutting, linear model, $\mathrm{R}^{2}=0.92 * *$} \\
\hline PADPR & $\mathrm{DMY}=0.404+0.0155 \mathrm{X}(\mathrm{b})$ & $77 \mathrm{~b}$ & PUPT $=0.214+0.0283 X(\mathrm{c})$ & $80 \mathrm{c}$ \\
\hline DTUK & $\mathrm{DMY}=0.404+0.0210 \mathrm{X}(\mathrm{a})$ & $104 \mathrm{a}$ & PUPT $=0.214+0.0426 \mathrm{X}(\mathrm{a})$ & $120 \mathrm{a}$ \\
\hline \multirow[t]{2}{*}{ SSP } & $\mathrm{DMY}=0.404+0.0202 \mathrm{X}(\mathrm{a})$ & $100 \mathrm{a}$ & PUPT $=0.214+0.0356 \mathrm{X}(\mathrm{b})$ & $100 \mathrm{~b}$ \\
\hline & \multicolumn{2}{|c|}{2 cuttings, linear model, $\mathrm{R}^{2}=0.92 * *$} & \multicolumn{2}{|c|}{2 cuttings, linear model, $\mathrm{R}^{2}=0.94 * *$} \\
\hline PADPR & $\mathrm{DMY}=1.08+0.036 \mathrm{X}(\mathrm{b})$ & $75 b$ & PUPT $=0.77+0.060 \mathrm{X}(\mathrm{b})$ & $71 \mathrm{~b}$ \\
\hline DTUK & $\mathrm{DMY}=1.08+0.045 \mathrm{X}(\mathrm{a})$ & $94 a$ & PUPT $=0.77+0.080 \mathrm{X}(\mathrm{a})$ & $90 \mathrm{a}$ \\
\hline \multirow[t]{2}{*}{ SSP } & $\mathrm{DMY}=1.08+0.048 \mathrm{X}(\mathrm{a})$ & $100 \mathrm{a}$ & PUPT $=0.77+0.085 \mathrm{X}(\mathrm{a})$ & $100 \mathrm{a}$ \\
\hline & \multicolumn{2}{|c|}{3 cuttings, linear model, $\mathrm{R}^{2}=0.87 * *$} & \multicolumn{2}{|c|}{3 cuttings, linear model, $\mathrm{R}^{2}=0.94 * *$} \\
\hline PADPR & $\mathrm{DMY}=2.35+0.053 \mathrm{X}(\mathrm{b})$ & $73 b$ & PUPT $=1.98+0.083 \mathrm{X}(\mathrm{c})$ & $65 \mathrm{c}$ \\
\hline DTUK & $\mathrm{DMY}=2.35+0.061 \mathrm{X}(\mathrm{b})$ & $84 b$ & PUPT $=1.98+0.105 \mathrm{X}(\mathrm{b})$ & $82 b$ \\
\hline \multirow[t]{2}{*}{ SSP } & $\mathrm{DMY}=2.35+0.073 \mathrm{bX}(\mathrm{a})$ & $100 \mathrm{a}$ & $\mathrm{PUPT}=1.98+0.128 \mathrm{X}(\mathrm{a})$ & $100 \mathrm{a}$ \\
\hline & \multicolumn{2}{|c|}{4 cuttings, linear model, $\mathrm{R}^{2}=0.82 * *$} & \multicolumn{2}{|c|}{4 cuttings, linear model, $\mathrm{R}^{2}=0.94 * *$} \\
\hline PADPR & $\mathrm{DMY}=3.27+0.063 \mathrm{X}(\mathrm{b})$ & $75 b$ & PUPT $=2.60+0.095 X(c)$ & $64 c$ \\
\hline DTUK & $\mathrm{DMY}=3.27+0.069 \mathrm{X}(\mathrm{b})$ & $82 b$ & PUPT $=2.60+0.118 X(b)$ & $80 \mathrm{~b}$ \\
\hline SSP & $\mathrm{DMY}=3.27+0.084 \mathrm{X}(\mathrm{a})$ & $100 \mathrm{a}$ & PUPT $=2.60+0.148 X(\mathrm{a})$ & $100 \mathrm{a}$ \\
\hline
\end{tabular}

$\dagger$ DMY and PUPT equations followed by the same letter in brackets within columns are not significantly different from each other $(\mathrm{P}=0.05)$

$¥$ Same lower case letter within columns indicates no significant difference between regression coefficients of the given equations $(\mathrm{P}=0.05)$

$\S R C R i$ followed by the same letter in within column per successive or cumulative cuttings are not significantly different from each other $(\mathrm{P}=0.05)$

** Significant at 0.05 probability level

regression models were tested to find the ones with best fit and characterized by common intercepts. Tables 4 and 5 give the response models together with their coefficients of determinations $\left(\mathrm{R}^{2}\right)$. The first two successive cuttings (Table 4) and all the cumulative dry matter yields and $\mathrm{P}$ uptakes at cuttings (Table 5) were best described as linear responses to $\mathrm{P}$ levels. The dry matter yield and $\mathrm{P}$ uptake at third and fourth successive cuttings were described as logarithmic responses to P levels. Overall, the models fit the $\mathrm{P}$ uptake data better than they did for dry matter yield as indicated by higher $\mathrm{R}^{2}$ values (Tables 4 and 5).

For each $\mathrm{P}$ source, RCRi, the ratio that represents the increase in dry matter yield or P uptake as compared with a standard source (SSP) per unit of P fertilizer applied, was computed and given in Tables 4 and 5. For the first cutting, the dry matter yield response functions (regression equations) for the SSP and DTUK were not significantly different. The response functions for $\mathrm{P}$ uptake were however, significantly different among the P sources. The PADPR and DTUK were $77 \%$ and $104 \%$ as effective as SSP in increasing dry matter yield of, and $80 \%$ and $120 \%$ as effective in increasing $\mathrm{P}$ uptake by ryegrass.

At the second cutting, the relative effectiveness of the $\mathrm{P}$ sources were of the order SSP $(100 \%)>$ DTUK $(88 \%)$ $>$ PADPR $(75 \%)>$ DPR $(0 \%)$ for dry matter yield and SSP $(100 \%)>\operatorname{DTUK}(75 \%)>\operatorname{PADPR}(62 \%)>\operatorname{DPR}(0 \%)$ for P uptake by ryegrass. For the combined first and second cuttings, the PADPR source was $75 \%$ and $71 \%$ as effective as SSP in increasing dry matter yield and P uptake, respectively. The effectiveness of DTUK was $94 \%$ as SSP in increasing dry matter yield and $90 \%$ in increasing $\mathrm{P}$ uptake. The relative effectiveness of the $\mathrm{P}$ sources in increasing dry matter yield and uptake followed the order $\mathrm{SSP}=\mathrm{DTUK}>\mathrm{PADPR}>\mathrm{DPR}=$ Check when first and second cuts were combined.

At the third and fourth successive cuttings, there were no significant differences between DTUK and PADPR on dry matter yield and P uptake. For the combined three 
cuttings and four cuttings, there was no significant difference between the dry matter yield response for DTUK and PADPR, but there were differences in P uptake as influenced by the $\mathrm{P}$ sources. The $\mathrm{P}$ uptake per unit increase in P applied was higher with SSP followed by DTUK. The relative effectiveness of DTUK and PADPR in increasing dry matter yield and $\mathrm{P}$ uptake with respect to SSP dropped when compared with results of the first two cuttings. The gap between the RCRi values of SSP and DTUK or PADPR widened, but that between DTUK and PADPR narrowed. The RCRi values (Table 4 and 5) obtained with P sources for the three and four cumulative cuttings show that the overall effectiveness of the $\mathrm{P}$ sources in increasing dry matter yield of, and $\mathrm{P}$ uptake by ryegrass followed the order of SSP > DTUK = PADPR, and SSP > DTUK > PADPR, respectively.

\section{Bray-1 Extractable $P$}

Very low amounts of $\mathrm{P}$ were extracted with Bray-1 after the fourth ryegrass (final) cutting (Table 6). On average, more $\mathrm{P}$ was extracted from soils treated with SSP. Analysis of variance showed no significant variance among $\mathrm{P}$ sources in extractable $\mathrm{P}$. There was also no significant correlation between $\mathrm{P}$ uptake or dry matter yield and Bray 1 extractable $\mathrm{P}$ at the end of the experiment.

Table 6. Bray 1 extractable $P$ after harvesting ryegrass from soils treated with $P$ sources

\begin{tabular}{lcccccc}
\hline & \multicolumn{6}{c}{ Rate of P app lication $\left(\mathrm{mg} \mathrm{P} \mathrm{kg}^{-1}\right.$ soil $)$} \\
\cline { 2 - 7 } P Source & 0 & 25 & 50 & 75 & 100 & 150 \\
\hline \multicolumn{5}{c}{ Bray-1 Extractable P $\left(\mathrm{mg} \mathrm{kg}^{-1}\right.$} & soil $)$ & \\
\cline { 2 - 7 } Check & 1.78 & & & & & \\
DPR & & 1.68 & 1.89 & 2.44 & 2.23 & 1.65 \\
PADPR & & 1.33 & 1.33 & 1.33 & 1.43 & 1.44 \\
DTUK & & 1.73 & 1.98 & 1.61 & 2.36 & 2.84 \\
SSP & & 1.99 & 1.78 & 3.69 & 5.39 & 4.93 \\
\hline
\end{tabular}

\section{DISCUSSION}

The results of this experiment showed that DPR was ineffective in increasing dry matter yield of, and $\mathrm{P}$ uptake by ryegrass despite the plant's fibrous rooting system that is best suited to utilize P from PR sources. Partially acidulating DPR increased the water plus citrate soluble $\mathrm{P}$ from $0.8 \%$ to $50 \%$ of SSP (Table 1). The increase in water soluble $\mathrm{P}$ results in increased $\mathrm{P}$ uptake and dry matter yield by plants (McLean and Wheeler, 1964). As this water-soluble P diminishes, the plant has to 'feed' on the less soluble portion of the $\mathrm{P}$ source and this may be the cause for the decline in RCRi values. The decline marks the transition from the readily available water-soluble $\mathrm{P}$ to the less plant available citrate-soluble P. After the transition, the P uptake was relatively steady as indicated by the uptake RCRi values (Tables 4 and 5). The ryegrass experiment also revealed that while partially acidulating Dorowa rock does not make the rock as effective as SSP, it does make it as effective as compacting the rock with TSP in the long run. This was indicated by the insignificant difference between RCRi values of DTUK and PADPR for dry matter yield of ryegrass for the third and fourth cuttings. That is, after about 12 weeks, both PADPR and DTUK had similar dry matter response curves to applied total $\mathrm{P}$ rates.

Results from the ryegrass experiment showed that DTUK was as effective as SSP in increasing dry matter yield of ryegrass during the first and second cuttings (12 weeks). During the first six weeks, DTUK resulted in significantly greater P uptake by ryegrass than SSP. After about 12 weeks DTUK and SSP were equal in their effect on P uptake by ryegrass. At about 15 weeks and more, SSP was more effective in increasing both dry matter yield and $\mathrm{P}$ uptake than DTUK because the available soluble P in SSP applications was two times greater than the available $\mathrm{P}$ in DTUK.

During the first six weeks, $\mathrm{P}$ uptake by ryegrass was higher with DTUK than with SSP (Table 2). This superiority by DTUK over SSP in P uptake by ryegrass may be due to differences in the P utilization efficiency as affected by soil properties. The rapid dissolution of the mostly watersoluble SSP may result in prolonged contact between dissolved $\mathrm{P}$ and the soil colloid because the rate of SSP dissolution could be higher than the rate of $\mathrm{P}$ uptake by the plant. The prolonged contact may lead to $\mathrm{P}$ reaction with soil to form plant unavailable compounds, thus reducing the amount of plant available $\mathrm{P}$ and consequently reduce the agronomic effectiveness of the $\mathrm{P}$ source (Mclean and Logan, 1970; Chien and Hammond, 1989). Therefore, although the dissolution of a P source in soil is a prerequisite for plant uptake, dissolution alone should not be used to indicate plant availability because soil factors such as P sorption capacity intervene (Mackay et al., 1986). When considering both the water plus citrate soluble P in P sources, it can be seen from Table 1 that the water plus citrate soluble P in DTUK and PADPR is about $50 \%$ of the amount in SSP. What this means is that the dry matter yield and P uptake of DTUK or PADPR at, for example, $100 \mathrm{mg} \mathrm{kg}^{-1}$ application rate, should effectively be the same as that for SSP applied at $50 \mathrm{mg} \mathrm{kg}^{-1}$ in terms of water plus citrate soluble $\mathrm{P}$ content. When these $\mathrm{P}$ 
Table 7: Average dry matter yield of, and $P$ uptake by ryegrass obtained three $P$ sources applied at 25,50 , and $75 \mathrm{mg}$ of water plus citrate soluble $\mathbf{P} \mathbf{~ k g}^{-1}$ soil

\begin{tabular}{|c|c|c|c|c|c|c|c|c|c|c|}
\hline \multirow{3}{*}{ P Sources } & \multicolumn{5}{|c|}{ Mean Dry Matter Yield $\left(\mathrm{g} \mathrm{pot}^{-1}\right)$} & \multicolumn{5}{|c|}{ Mean P Uptake (mg pot $\left.{ }^{-1}\right)$} \\
\hline & \multicolumn{4}{|c|}{ Cuttings } & \multirow[t]{2}{*}{$\overline{\text { Total }}$} & \multicolumn{4}{|c|}{ Cuttings } & \multirow[t]{2}{*}{ Total } \\
\hline & 1 & 2 & 3 & 4 & & 1 & 2 & 3 & 4 & \\
\hline PADPR & $1.89 \mathrm{~b}$ & $2.64 b$ & $2.97 \mathrm{~b}$ & $1.91 \mathrm{ab}$ & $9.40 \mathrm{~b}$ & $2.95 b$ & $3.59 b$ & $3.57 \mathrm{~b}$ & $1.81 \mathrm{~b}$ & $11.83 b$ \\
\hline DTUK & $2.54 \mathrm{a}$ & $3.15 \mathrm{a}$ & $2.93 b$ & $1.80 \mathrm{~b}$ & $10.42 \mathrm{a}$ & $4.49 \mathrm{~b}$ & $4.31 \mathrm{a}$ & $3.73 b$ & $1.98 \mathrm{a}$ & $14.51 \mathrm{a}$ \\
\hline SSP & $1.44 \mathrm{c}$ & $2.50 \mathrm{~b}$ & $3.54 \mathrm{a}$ & $2.06 \mathrm{a}$ & $9.55 \mathrm{~b}$ & $2.00 \mathrm{c}$ & $3.50 \mathrm{~b}$ & $4.38 \mathrm{a}$ & $2.01 \mathrm{a}$ & $11.98 \mathrm{~b}$ \\
\hline Lsd & 0.31 & 0.3 & 0.28 & 0.19 & 0.52 & 0.54 & 0.44 & 0.35 & 0.14 & 0.87 \\
\hline
\end{tabular}

$†$ Mean values within the same column with same letter are not significantly different at 0.05 probability level.

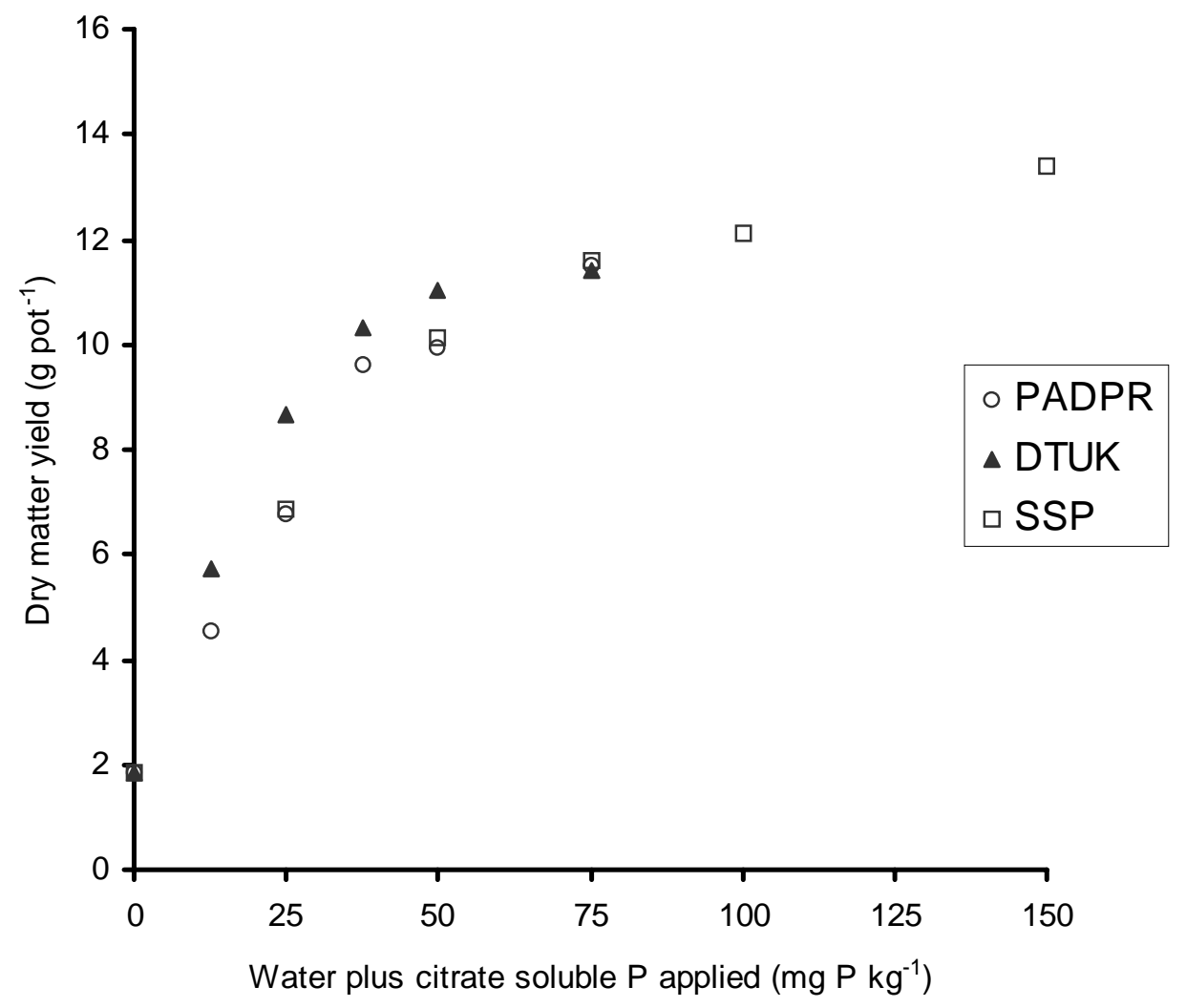

Figure 1: Relationship between the total cumulative dry matter of ryegrass and rates of water plus citrate soluble $P$ applied 


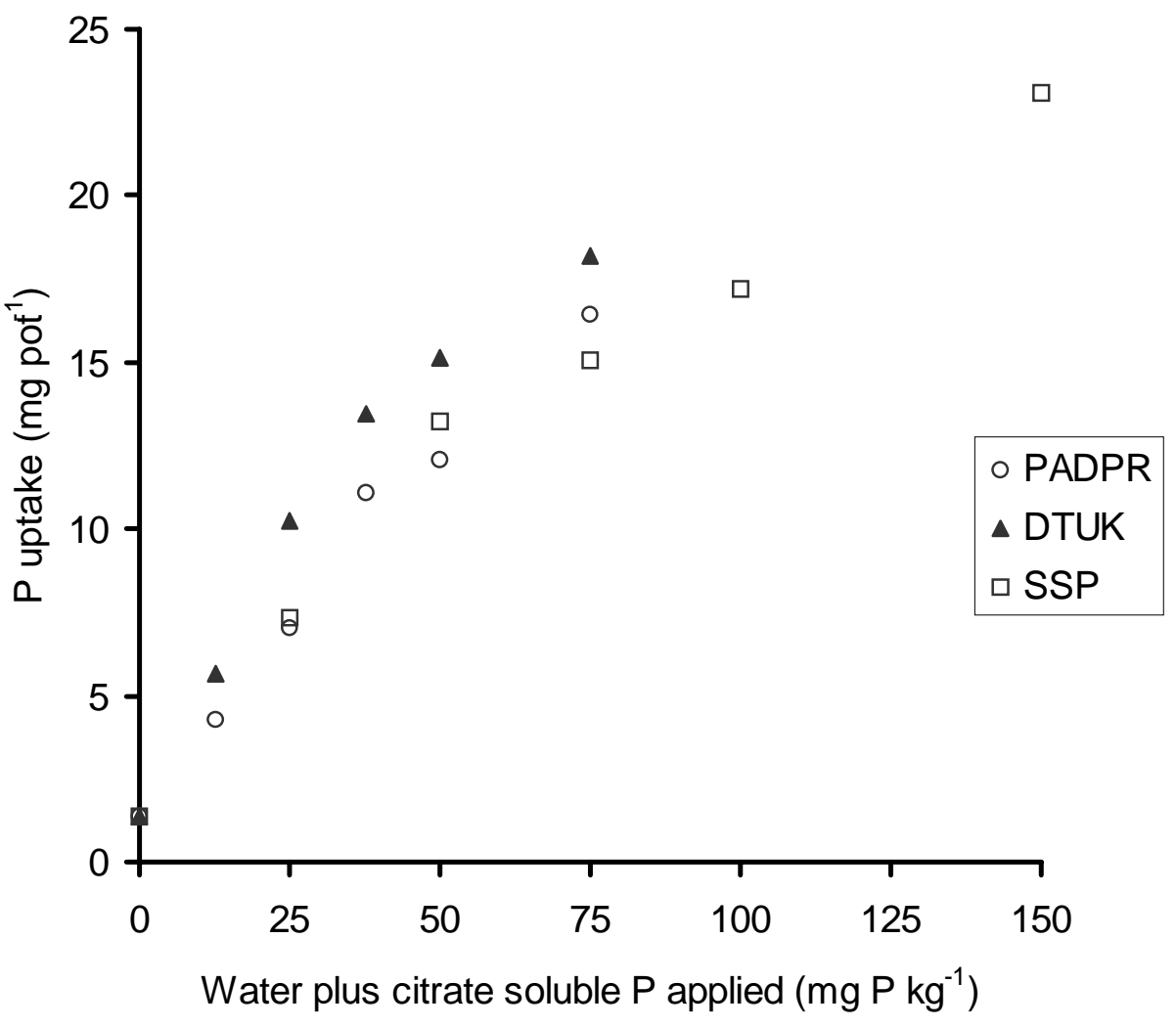

Figure 2: Relationship between the total cumulative $P$ uptake by ryegrass and rates of water plus citrate soluble $P$ applied

sources are compared based on per unit of $\mathrm{P}$ from the water plus citrate soluble P applied, the cumulative dry matter yield and P uptake for DTUK are greater than SSP (Table 7, Figures 1 and 2). Data for SSP for water plus citrate $\mathrm{P}$ application rates above $75 \mathrm{mg} \mathrm{kg}^{-1}$ are excluded. Because the cumulative DTUK dry matter and P uptake are significantly greater than SSP, at least up to $75 \mathrm{mg} \mathrm{kg}^{-1}$ (Table 7), this indicates that in addition to the water plus citrate soluble P component of DTUK, the unreacted phosphate rock component contributes to the increase in dry matter yield of, and $\mathrm{P}$ uptake by ryegrass. The logical explanation for the agronomic effectiveness of the DTUK is that compacting the Dorowa rock with TSP is equivalent to partial acidulation processes. Both processes produce the same major ingredients, namely, depleted PR and water-soluble P. When the more soluble TSP dissolves, formation of $\mathrm{H}_{3} \mathrm{PO}_{4}$ is induced by the hydrolysis of monocalcium phosphate (Chien and Menon, 1995). The $\mathrm{H}_{3} \mathrm{PO}_{4}$ reacts with the rock creating a partial acidulated $\mathrm{P}$ fraction that is available to plants. This in situ partial acidulation is the key to the early growth effectiveness of DTUK compared to the other sources.
If the response curves for the SSP, DTUK, and SSP were the same, it would indicate that the ryegrass responded only to water plus citrate soluble $\mathrm{P}$ component and that the unreacted DPR component makes no contribution. This seems to be the case with PADPR. The PADPR is less than DTUK but similar to SSP. This indicates that the ryegrass growth and $\mathrm{P}$ uptake responded only to the water plus citrate soluble $\mathrm{P}$ component in the PAPR and the unreacted phosphate rock component made no contribution. These results on PADPR are similar to Xiong et al. (1994) and Ghani and Rajan (1997). They found that in the case of partially acidulated phosphate rocks, the agronomic performance was mostly dependent on the water-soluble fraction of acidulated rock. The contribution of the insoluble fraction of the acidulated rock was insignificant.

Another possible reason for the effectiveness of DTUK is that the presence of more than one nutrient in the granule, or briquettes as is the case with DTUK product, may increase crop response due to "starter" and "synergistic" effects. The simultaneous presence and availability of multinutrients 
in a granule has greater agronomic effect on early plant-root development. Leikam et al. (1983) proposed that the presence of ammoniacal $\mathrm{N}$ fertilizer increases $\mathrm{P}$ availability because of the synergistic effect of mixing $\mathrm{N}$ and $\mathrm{P}$ together. Compacting $\mathrm{N}$ and $\mathrm{P}$ together should therefore increase the synergistic effect on $\mathrm{N}$ and $\mathrm{P}$ uptake by enhancing the interaction between $\mathrm{N}$ and $\mathrm{P}$ in the granules and in soil. The resultant early plantroot development enables the plant to use the unacidulated PR component more effectively (Chien and Hammond, 1988). This may explain why DTUK had the highest $\mathrm{P}$ uptake per total P applied during the first cutting. It was $120 \%$ as effective as SSP during the first ryegrass cut based on total P applied (Table 4). For SSP and PADPR, about $60 \%$ of the
P uptake amounts came from the second and third cuttings whereas for DTUK, $60 \%$ came equally from the first and second cuttings.

The changes in RCRi values for $\mathrm{P}$ uptake did not necessarily match the values for dry matter yield. This is expected since $\mathrm{P}$ uptake is a 'lead' indicator and dry matter yield is a 'lag', i.e. there is a time lag between $P$ uptake and effect of the taken up P on the dry matter yield.

Even though the DTUK and PADPR were effective in increasing dry matter yield of, and P uptake by ryegrass, their adoption as $\mathrm{P}$ sources depends not only on agronomic

Table 8: Amount of $P$ sources required to provide $100 \mathrm{~kg}$ of water plus citrate soluble $\mathrm{P}_{2} \mathrm{O}_{5}$

\begin{tabular}{lccc}
\hline \multicolumn{1}{c}{ P Source $\dagger$} & Total $\mathrm{P}_{2} \mathrm{O}_{5}, \%$ & Water + Citrate $\mathrm{P}_{2} \mathrm{O}_{5}, \%$ & $\begin{array}{c}\text { Amount of P Source Needed for } \\
100 \mathrm{~kg} \text { Water }+ \text { Citrate } \mathrm{P}_{2} \mathrm{O}_{5}\end{array}$ \\
\hline DPR & 33.3 & 0.8 & 12500 \\
PADPR & 25.2 & 9.8 & 1020 \\
DTUK & 16.6 & 9.3 & 1075 \\
SSP & 19.4 & 18.6 & 538 \\
\hline
\end{tabular}

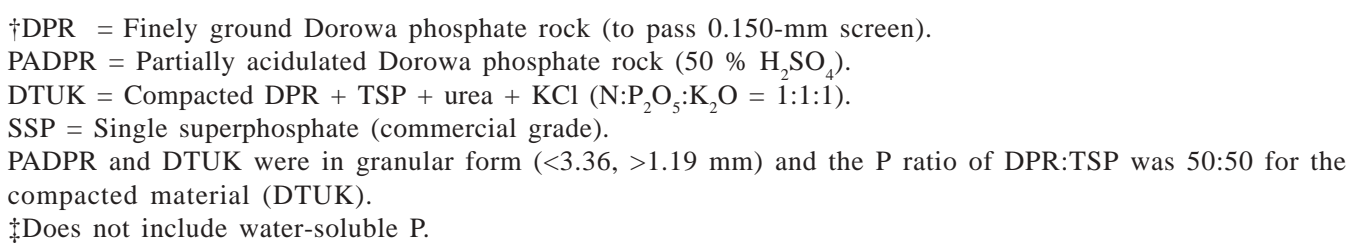

effectiveness but other factors such as fertilizer policy, and production and distribution costs. Just as an example of transportation cost, Table 8 shows equivalent amounts of PADPR, DTUK, and SSP required to supply $100 \mathrm{~kg}$ of water plus citrate soluble $\mathrm{P}_{2} \mathrm{O}_{5}$. It can be seen that the weight ratio of DTUK and PADPR to SSP is $2: 1$. The agronomic substitution ratio similar to the RCRi values, but based on water plus citrate soluble $\mathrm{P}$, may not be high enough to cover added costs such as packing and transportation. However, DTUK has an advantage over PADPR in that it is a multi-nutrient $\mathrm{P}$ source.

\section{Bray 1 Soil Tests}

The Bray 1 extractable amount of $\mathrm{P}$ left in soil after ryegrass was very low. Analysis of variance showed no significant differences in Bray $1 \mathrm{P}$ among $\mathrm{P}$ sources. The correlation between extracted $\mathrm{P}$ at the end of the experiment and dry matter yield or uptake was poor, especially with Dorowa based fertilizers. One of the reasons is that with slow reactive $\mathrm{P}$ sources, such as $\mathrm{PRs}$, the dissolved $\mathrm{P}$ may be taken up by plants or fixed by soil compounds as soon as it enters the soil solution because of the low $\mathrm{P}$ activity in soil solution. Therefore, the extracted amount would tend to underestimate the availability of $\mathrm{P}$ from these $\mathrm{P}$ sources and the correlation between plant yield and $\mathrm{P}$ uptake becomes poor

\section{CONCLUSION}

Dorowa phosphate rock is ineffective as a $\mathrm{P}$ source even on an acid soil like Hartsells that was used in this experiment and even with a plant such as ryegrass that is efficient in $\mathrm{P}$ uptake from PRs. The rock has to be modified if it is to be used as a P source. Two modifications, (1) partially acidulating the rock, and (2) compacting the rock with $\mathrm{TSP}$, urea, and $\mathrm{KCl}$, represent promising alternatives to utilize DPR for crop production. On a water plus citrate soluble P basis, PADPR is just as effective as SSP. The most effective alternative to using DPR or PADPR is to 
use DTUK as the P source. It results in higher dry matter yield and P uptake than PADPR and may not require as much capital investment and manpower skills. Such technologies are most appropriate for developing countries.

\section{ACKNOWLEDGEMENTS}

The authors gratefully acknowledge the financial support of the United States Agency for International Development, the International Fertilizer Development Center, and the University of Zimbabwe.

\section{REFERENCES}

Becker, P. 1989. Phosphate and phosphoric acid. Raw materials, technology, and economics of wet process. Marcel Dekker, Inc. New York.

Bray, R.H, and L.T Kurtz. 1945. Determination of total, organic and available forms of phosphorus in soils. Soil Science 59:39-45.

Chien, S.H., and R.G. Menon. 1995. Agronomic evaluation of modified phosphate rock products. Fert. Res. 41:197209.

Chien, S.H., P.G.W. Sale, and D.K. Friesen. 1990. A discussion of the methods comparing the relative effectiveness of phosphate fertilizers varying in solubility. Fert. Res. 24:149-157.

Chien, S.H, and L.L. Hammond. 1989. Agronomic evaluation of partially acidulated phosphate rocks in the tropics. IFDC paper series P-7. International Fertilizer Development Center, Muscle shoals, AL. USA.

Chien, S.H., and L.L. Hammond. 1988. Agronomic evaluation of partially acidulated phosphate rocks in the tropics: IFDC's experience. Paper Series IFDC-P7, International Fertilizer Development Center, Muscle Shoals, AL, USA.

Chien, S.H., D.T. Hellums, and J. Henao. 1986. Greenhouse evaluation of elemental sulfur and gypsum for flooded rice. Soil Sci. Soc. Am. J. 51:120-123.

Ghani, A., and S.S.S. Rajani. 1997. Differential availability of partially sulphuric and phosphoric acidulated phosphate rocks I. Plant Response. Nutr. Cycl. Agrosy. 47:251-259.

Govere, E., S.H. Chien, and R.H. Fox. 2004. Evaluation of dissolution of nonconventional phosphate fertilizers in Zimbabwe soils: Effects of soil properties. Afric. J. Sci. Techn. 5(2) (in press).

Govere, E. S.H. Chien, and R.H. Fox. 2003. Agronomic Effectiveness of novel phosphate fertilizers derived from an igneous Zimbabwe phosphate rock. African Crop Sci. J. 11(3):235-241.
Govere, E.M., S.H. Chien, and R.H. Fox. 1995. Residual effects of novel phosphate fertilizers derived from Dorowa rock, Zimbabwe. J. Applied Sci. Southern Africa 1:41-46.

Hammond, L.L., S.H. Chien, and A.U. Mokwunye. 1986. Agronomic value of unacidulated and partially acidulated phosphate rocks indigenous to the tropics. Adv. Agron. 40:89-140.

Hellums, D.T., S.H. Chien, and J.T. Touchton. 1989. Potential agronomic value of calcium in some phosphate rocks from South America and West Africa. Soil Sci. Soc. Am. J.53:459-462.

Khasawneh, F.E., and E.C. Doll. 1978. The use of phosphate rock for direct application. Adv. Agron. 30:159-206.

Khasawneh, F.E., and J.P. Copeland. 1973. Cotton root growth and uptake of nutrients: relation of phosphorus uptake to quantity, intensity, and buffering capacity. Soil Sci. Soc. Amer. Proc. 37: 250-254.

Leon, L.A., W.E. Fenster, and L.L. Hammond. 1986. Agronomic potential of eleven phosphate rocks from Brazil, Colombia, Peru, and Venezuela. Soil Sci. Soc. Am. J. 50:798-802.

Leikam, D.F., F.S. Murphy, D.S. Kissell, D.A. Whitney, and H.C. Moser. 1983. Effect of nitrogen and phosphorus application method and nitrogen source on winter wheat grain yield and leaf tissue phosphorus. Soil Sci. Soc. Am. J. 47:530-535.

Lupin, M.S., and N.D. Le. 1983. Alternative approach for granular fertilizers: Compaction. Technical Bulletin T25. IFDC, Muscle Shoals, AL.

Mackay, A.D, J.K. Syers, R. W. Tillman, and E.H. Gregg. 1986. A simple model to describe the dissolution of phosphate rock in soils. Soil Sci. Soc. Am. J. 50:291-296.

McClellan, G.H., and A.J.G. Notholt. 1986. Phosphate deposits of Sub-Saharan Africa. p 173-223. In A.U. Mokwunye and P.L.G. Vlek (ed.) Management of nitrogen and fertilizers in Sub-Saharan Africa. Martinus Nighoff, Dordrecht, Netherlands.

McLean, E.O., and T. J. Logan. 1970. Sources of phosphorus for plants grown in soils of differing phosphorus fixation tendencies. Soil Sci. Soc. Am. Proc. 34:907-911.

McLean, E.O., and R.W. Wheeler. 1964. Partially acidulated rock phosphate as a source of phosphorus to plants: 1. Growth chamber studies. Soil Sci. Soc. Am. Proc. 28:545-550.

Menon, R.G., and S.H. Chien. 1990. Phosphorus availability to maize from partially acidulated phosphate rocks and phosphate compacted with triple superphosphate. Plant and Soil 127:123-128. 
Roy, A.H., and G.H. McClellan. 1985. Future prospects for nonconventional phosphate fertilizers in developing countries. Paper presented at the 1985 Autumn meeting of the Raw Materials Committee of the International Fertilizer Industry Association, Kyoto, Japan, October 15-16. IFDC, Muscle Shoals, AL.

SAS Institute Inc. 1990. SAS/STAT Users Guide, Version 6, Fourth Edition. Volume 2. SAS Institute Inc., Cary, N.C. USA.

Schultz, J.J. 1986. Sulfuric acid-based acidulated phosphate rock. Its production, cost and use. Tech. Bull. IFDC OT-31. Muscle Shoals, AL.
Steel, R.G.D., and J. Torrie. 1980. Principles and procedures of statistics, A biometric approach. McGraw-Hill Book Company, New York.

Van Kauwenbergh, S.J. 1989. Overview of phosphate deposits in East and Southern Africa and mineral activity to date. p.5-50. In S.J. Van Kauwenbergh et al. (ed.) East and Southern Africa Geology Workshop on fertilizer Minerals. IFDC, Muscle Shoals, AL.

Xiong, L.M., R.K. Lu, and B. Truong. 1994. An evaluation of the agronomic potential of partially acidulated rock phosphates in calcareous soil. Fert. Res. 38:205-212.

Watanabe, F.S., and S.R. Olsen. 1965. Test of an ascorbic acid method for determining phosphorus in water and $\mathrm{NaHCO}_{3}$ extracts from soil. Soil Sci. Soc. Proc. 29:677678. 